\title{
Use of Reflective Journals in Development of Teachers' Leadership and Teaching Skills"
}

\author{
Suleyman Davut Göker \\ Department of Educational Sciences, Faculty of Education, Artvın Coruh University, Turkey
}

Copyright $\bigcirc 2016$ by authors, all rights reserved. Authors agree that this article remains permanently open access under the terms of the Creative Commons Attribution License 4.0 International License

\begin{abstract}
Focusing on the contribution of reflective practice to teaching practice amongst student teachers, this study examines the impact of reflective journal entries of 16 student teachers from Faculty of Education at the Artvin Coruh University in Turkey. Quantitative and qualitative research approaches were employed for this study including open-ended questioning techniques (surveys and interviews), written reflections under reflective categories showing how the participants reflected on their teaching experience as anecdotal data. Participants were trained through a $10-\mathrm{h}$ orientation on reflective writing program developed by the researcher. To categorise the reflective writing types, identification of Hatton and Smith [12] of types of reflection (instrument 1), was employed. Participants were later requested to answer a 26 open-ended questionnaire (instrument 2), the questions of which were constructed based on Richards and Lockhart's [16]. Findings have implications for how reflective journals can be employed and used in school-based contexts and pre-service teacher education.
\end{abstract}

Keywords Student Teachers, Reflective Journals, Leadership, Teaching Skills, Reflective Writing Strategies

\section{Introduction}

Journal writing is widely used in many educational contexts. As an individual activity, in a reflective journal, teachers put their thoughts, ideas, feelings and reflections [21]. İt is also possible to conduct reflections orally [5]. After observing what is actually happening in the classroom and school, teachers keep notes in either dialogue journals, learning logs, personal narratives or diaries. These notes include different reflections, which provide them with a critical analysis of what they do in class and help them discover alternative steps to develop reflective practice. Guided reflective practice through using reflective journals not only provides teachers with enough direction but also allows for teacher autonomy. However, nearly all activities carried out based on journal writing strategy require practice using reflective and experiential learning cycle. The improvement of reflective capacity could be implemented in different ways such as individual activities and journaling to group discussion and dialogue.

\subsection{Reflection and Reflective Journals}

Reflective or learning journals are considered to be one of the most common strategies employed because of the practical utilization. They have mainly been utilized in different study fields such as literature, healthcare and mathematics. The structure and format of reflective journals could include free stream-of-consciousness writing or a structured analysis of critical events. The essential goal is to develop self-awareness and have a better concept comprehension ([6]; [20]; [15]).

Many research studies have focused on investigating reflection in teacher education using wide variety of journals. Diaries and dialogue journals are known to be the most popular ones [1]. To promote reflective thinking in teaching, reflective journals are commonly used in research studies on different disciplines and teacher education ([2]; [7]; [9]; [13]; [14]).

One good example for reflective journals is that of Hatton and Smith [12]. 60 teacher education students from the Sydney University were included in the research study on the use of reflective journals (1991 and 1992 cohorts). The impact of strategies and tasks structured students were exposed to in the teacher education program was the main focus in the study. However, there is not much scholar work on the task of writing journal focusing on positive effects of considerable potential for teacher development. The main reason for this is that critical analysis of teaching is a tough process for the student teachers having little or no experience in the classroom. Within this context, this study is expected to serve teacher education programs enabling them a sample training program on how to reflect on their teaching through reflective journals. 


\subsection{Why Use Reflective Journals?}

Questioning the current in-service teacher training, this study also introduces a school-based reflective learning environment where teachers learn how to write and use reflective journals, which provide teachers with new experiences and develop reflective leadership skills. Journal writing, within this context, is considered to be new learning tools for teachers to create an awareness on their current practice. Through reflective journals aiming to create critical environments, teachers can provide other teachers with an opportunity to reflect on their existing considering other optional methods and develop reflective leadership.

The other consideration in this study is that current pre-service teacher education programs in Turkey do not to provide student teachers with enough opportunities to think critically on their present practice and learn about other experiences and approaches due to a huge number of theory-based courses offered in the B.A. programs. They are not designed to help student teachers to be exposed to learning environments where they will experience evaluation based on self-analysis. Under the current in-service teacher training system of Turkey, one can hardly say the student teachers learn how to reflect through analysis, acquisition of facts, synthesis, application of principles, understanding of ideas, and evaluation. On the other hand, they do not have reflective learning environments where they can develop and learn through regular practice, which includes responses to questions relating to the why, what, and how of different learning and teaching contexts. Both the inadequate number of hours allocated for teaching practice and the demands on students teachers introduced by theory-based courses have led many to question the quality of the real time spent for teaching practice and collaboration for better learning and teaching.

Ultimately, teachers should be able to reflect, analyze, and change their practice when necessary. When reflective journal writing process is performed, the results gained will benefit student's teachers to become better teachers.

\subsection{Hypothesis and Research Questions}

Based on the discussion outlined above, three research questions are posed because this study attempts to reveal the effect of reflective journals on the teaching performance of student teachers.

1. What reflection types are observed in the student teachers' writing?

2. What strengths and weaknesses were focused by the student teachers' on writing their reflection?

3 . What are the student teachers' opinions regarding 10 -hour orientation on reflective writing program?

\section{Methodology}

\subsection{Participants}

This study was carried out during the Spring term of
2015-2016 Academic Year at the Artvin Coruh University in Turkey. 16 student teachers ( 8 female, 8 male) from pedagogical formation certificate program were included in the study while taking their teaching practice course (PF506). The student teachers with little or no teaching experience were enrolled in the six-month pedagogical formation certificate program, All of them were from the department of Sociology, Faculty of Letters of the same university.

\subsection{Data Collection}

Data were collected during the reflective implementation of the Teaching Practice course. The goal of this study was to examine the impact of reflective journal entries of 16 student teachers investigating the reflection types, strengths and weaknesses of them, and opinions of them in terms contribution of reflective journal writing to their teaching. Student teachers were familiar with the idea of reflection when they started their teaching practice. They were asked to write their entries as often as possible in a reflective journal. No information on how to write was given and they were requested to put their daily teaching experiences in classes. However, the purpose of writing a journal was informed to them.

Quantitative and qualitative research approaches were employed for this study including open-ended questioning techniques (surveys and interviews), written reflections under the categories showing in what ways the respondents reflected on their teaching experience as anecdotal data. Frequency analysis was employed to show the distribution of types of reflection. Before the 7-week research study, they were trained through a 10-h orientation on reflective writing program developed by the researcher. To categorise the reflective writing types, identification of Hatton and Smith [12] of types of reflection (instrument 1), was employed. Participants were later requested to answer a 26 open-ended questionnaire (instrument 2), the questions of which were constructed based on Richards and Lockhart's [16], to examine their perceptions of writing journal. Only 14 journals, in which there was a total of 200 entries, which were taken into consideration.

\subsection{Data Analysis}

The 14 journals were randomly split into two different piles and the entries were analysed by the researcher considering the categorisation of reflective writing types. For the categorisation or types of reflective writing, Hatton and Smith's identification [12] of types of reflection was employed. It took the researcher between 3 to 4 weeks to finish the content analysis for different reflective writing types. Each single entry was scanned and identified as critical reflection, dialogic reflection, descriptive reflection or descriptive writing considering Hatton and Smith's identification of types of reflection. Some overlap in some entries was found (for a sample of different reflective writing types, see Appendix I). 


\section{Findings}

\subsection{Research Question One}

Research question one of this research study aims to explore the types of reflection evidenced in the student teachers' writing. To answer this research question, the types of reflection evidenced in the student teachers' writing were analysed. Findings (Appendix II) revealed that the order of the types of entire followed this path: Dialogic Reflection (35\%), Descriptive Writing (29\%), Critical Reflection (26\%) and finally Descriptive Reflection (10\%).

Within the framework of dialogic reflection of the respondents, the main was on techniques of teaching, classroom management, and teaching aids. For example, a student teacher pointed that the teaching method she used did not work because it did not take different learning styles and abilities into consideration. In one entry, the student teacher said that due to the lack of the authenticity, the students were demotivated. He commented that whatever you teach, the content should be relevant to students' real life experiences. The other striking fact evidenced in the entries of Descriptive type was that student teachers failed to describe the answers to the problems, so the researcher had to have initiative to lead them to discussions. However, Critical Reflection type provided them an in-depth picture of the situation and they increased awareness on the problems identified.

Through a deeper analysis, DIAR type was found to be effective in revealing the events both in class and school context. In another entry, student teacher admitted that they were not familiar enough with study skills and test taking strategies. That is why some techniques were refreshed to help her answer discussion questions. One student commented on her reflection during the 7 -week practice teaching program:

A teacher's job is more than giving information. Within the 7-week practicum, what I have acquired is so dear for me in terms of understanding the implications of learning theories. As a teacher, I feel that I am supposed to have the power to courage my students to achieve both morally and academically.

In one of the entries, s student teacher said that what I have learned from my theory-based lessons about teaching and learning principles during the B.A. program is so different from I have been doing in the classroom context:

I now realize the importance of time management. During the pre, while and post sections of the lesson, I overestimated time management principles. Furthermore, I did not know that teacher talk time in my teaching would be much more than learner talk time. How should I arrange it?

Reflecting on the importance of school culture in the school, a student teacher underlined the importance of collaboration between school and parents. Based on the information he collected during the observation, he said that they should also be aware of how some behaviours and situations are affected by the school culture directly and indirectly.

Among the major disciplinary problems are skipping school and occurrence of truancy. Effective collaboration between school and parents is needed to overcome this problem as schools are not the only responsible party.

In another entry, a student teacher mentioned about the contribution of preparation of authentic material. According to him, teachers must make extra effort to prepare their own materials apart from the course book.

I feel that my class was really involved in discussions about being a good citizen. They really liked the material we prepared about being a good citizen as it is the current issue they have been discussing with their parents.

A student teacher said that at the pre-stage of the lesson, I directly asked questions to create curiosity as part of brain storming. However, it did not work. The introduction part of the lesson was not interesting and my questions were not about their real life experiences, so I lost the control.

During the 10-hour orientation program, I had actually learnt how I would begin a lesson. I could have used a video script form a popular film about the topic or something reflecting examples, in which there could have been results of not obeying those rules.

Another student in one of the entries said. I had forgotten to state his objectives. I did not clearly tell them what they would learn. I could begin with my objectives, talk about the contribution of the discussion point to our daily life.

In the 7-week practicum, I actually learned how I would state my objectives. However, I managed to divide my students in groups for role play let them talk about it and thus take them back to the large group in the pre-section of the lesson.

As can be seen, student teachers preferred to write not reflecting critically but in the other types of reflection. As previously mentioned, much more time is need for the type of reflection and it is more challenging and requires knowledge and experience. However, it is our expectation that this type of reflection can probably develop over time.

\subsection{Research Question Two}

Research question two of this research study aims to explore the strengths and weaknesses experienced by the student teachers' on writing their reflection.

A student teacher, in one entry,

I think my biggest area 'needs improvement' is classroom management. Because, during my practicum I have realized that each student in the class is exhibiting different disruptive behavior. I need more time and experience to understand them. I am pretty new at this. That means that I have no experience to guide me in all of the split-second 
questions that come up over the course of the day.

In another entry, a student teacher said,

I tend to be over friendly to students, what is not always good. Nevertheless, I am aware of this and try to keep some distance. When examined my strengths, I can talk about good listening skills and an ability to grasp the problems and emotions of the students in a short time.

In an entry, a student teacher said

I include so many creative activities in my class, however, time is not enough. Incorporating all of the activities my students would like is tough. However, I have learnt how to prioritize the most important lessons to courage my students in the course of time. I may say that doing everything I wish is not easy.

In a different entry, a student teacher said

Every student is unique and to win the heart and belief of each student, I approach everyone individually. This seems to be my strength. But, I try to treat everyone equally regarding ranking, as it would be very demotivating for the better children to get the same marks as the others get. Meanwhile, I am quite open to use both attitudes, equal and not equal, depends on the philosophy of your school. Teachers must be unified in this.

In another entry, a student teacher said

My greatest strength as a teacher, I feel, is my ability to relate to the students and to employ different methods incorporating other disciplines. I have now learnt quite practical tips to help students learn through reflective writing program. What I learned here will definitely make me incorporate different concepts of role play into my teaching of sociology in many ways.

In an entry, a student teacher said

Flexibility, passion for children and teaching, compassion, hard work, and professionalism in a classroom are my greatest strengths as a teacher. This program helped me to be aware of all of my strengths for teaching.

In a different entry, a student teacher said

I believe my biggest weakness is to fail to understand and have a great rapport with my students. I do not have enough experience, but I will try to learn how to interact with students in a natural setting.

As can be seen, the main concern of the student teachers in the overall reflective writings seems to be on teaching techniques, classroom management, preparing authentic materials, in particular, teaching aid suitable for every lesson and classroom management strategies like managing disciplinary problems. Increasing the motivation levels of students is also a recurring concern. In their reflection, the student teachers also include writings on the collegial atmosphere or lack of between the teachers and administrators. However, almost all of them admit that they lack experience but they further add that their greatest strength as a teacher is simply a love of what they will do and a dedication to their students.

\subsection{Research Question Three}

Research question three aims to explore student teachers' opinions regarding 10-hour orientation on reflective writing program. To answer this research question, student teachers' were asked to respond to a 26-question survey on their opinions regarding 10-hour orientation on reflective journal writing program (For the questions on the questionnaire see Appendix III). All respondents (n16) filled in questionnaire and they were all analyzed. Participants were asked to state to what extent they were satisfied with the reflective journal writing program.

According to the responses received, an overwhelming majority of them (91\%) gave positive responses and meaningful comments in favour of the reflective journal writing program. In addition, a great majority of them $(81 \%)$ found the training very useful and they stated that it created an awareness on their strengths and they had the chance to develop in in identifying problems in their teaching. Again most of them $(73 \%)$ stated that they developed new understanding towards being a better, wise, creative teacher. Almost $68 \%$ of them indicated that they realized new strategies to analyze the problem solving approach employed in their teaching. $60 \%$ of the participants stated that they saw progress in understanding learning theories used during teaching and learning process. However, almost $5 \%$ of them stated that they were not satisfied with the writing a reflective journal.

A great majority of the student teachers stated that reflective journal writing assisted them in grasping their teaching and learning process along with identifying obstacles and mistakes in their teaching. The respondents wrote their thoughts about the school, the way they teach and, to a large extent, as facilitative in

(a) evaluating the activities used,

(b) improving themselves as a teacher,

(c) determining changes to be made during teaching,

(d) reflecting on the theories they have acquired and the applicability these theories to actual practice,

(e) determining the effective or ineffective aspects of teaching,

(f) determining a good, creative and effective teacher characteristics.

(g) carrying out the teaching objectives of a lesson,

(h) evaluating the teaching aids and methods used,

(i) revealing problems encountered in their teaching,

(j) bringing solutions to the problems encountered,

(k) evaluating teacher-student relationships, 
(l) evaluating their approach to the needs of students,

(m) grasping the learning and teaching process and the curricula.

To sum up, when carefully examined the reflective journal writing experience, almost $83 \%$ of the participants indicated that the task helped them evaluate their strengths and weaknesses, teaching methods used, awareness of their own teaching, problems encountered in teaching, determining authenticity for aids and materials to be used during. The following common themes took place in their responses:

1. Helps in the evaluation of their weaknesses and strengths.

2. Helps in employing the right teaching method in different contexts.

3. Assists in preparing the authentic material when the course book fails.

4. Helps in determining problems encountered in teaching, and solutions to them.

\section{Conclusions and Recommendations}

Results gained through this study are also consistent with those of some researchers showing the positive contribution of journal writing ([2]; [7]; [13]; [14]; [18]; [19]). Taking the recent developments based on creating reflective communities and reflective practices in the field into consideration, I argue that writing reflective journals could be integrated with the content of teacher education programs. As long as writing reflective journals is included in those programs, countless benefits could be gained and they could be carried out in other learning and teaching contexts [10].

This type of implication for programs in teacher education can include the explicit training or development of both teaching and leadership skills to help student teachers reflect upon their practice and thus develop reflective leadership skills. It is not a difficult process for the teachers to be exposed to reflective journal writing in school contexts and for the prospective teachers during their teaching practice. Discussions with lecturers and peers, authentic samples of journal entries or reflective journals written during macro or micro teaching courses constitute the core elements of reflective teaching and reflective leadership practice [11].

Whatever mechanism is used to stimulate reflective practice, its incorporation into the learning process creates reflective learning communities to develop "reflective leaders." Within this context, the action-reflection cycle could be initiated earlier in a student teacher's teaching practice, and implements as often as possible. This research study is believed to have created some suggestions for in what ways teacher trainers could facilitate the development of reflective practice through writing journals. Some questions employed in journals like "in what other ways are we going to do next time or what changes in my thinking have I gained through such an experience" could even form reflective habits through enhanced learning when implemented systematically. Within this context, reflective practice is believed to contribute to analytical learning. Even though reflective journaling is easy to implement, other more collaborative methods could also be employed to enhance teachers' individual and group learning realizing the fact reflective practice and learning is a lifelong experience.

Prospective teachers through reflective journals developed in their leadership and teaching skills. The findings also showed that a great majority of participants are happy with their progress through such a training. They stated that they increased their awareness in evaluating their own current practice, which is the main scope of reflection. To conclude, this type of training could play a key role in forming efforts based on collaboration and a potentially serviceable solution for developing teacher effectiveness both in pre-service and in-service contexts. It could also be an inexpensive and feasible asset in all school contexts. 


\section{Appendix}

\section{Appendix I: Reflection Types}

\section{1. (DIAR) Dialogic Reflection}

\begin{tabular}{|c|c|c|}
\hline Journal No. & Date & Journal Excerpt \\
\hline 13 & $3-3-16$ & $\begin{array}{l}\text { I have realized that each student in the class is exhibiting different disruptive behavior. I need more time and } \\
\text { experience to understand them. I am pretty new at this. That means that I have no experience to guide me in all } \\
\text { of the split-second questions that come up over the course of the day. I happened to ask the student why she was } \\
\text { not listening to me. Her response was "do not like philosophy". I got shocked. The student told that she had to } \\
\text { take this course as elective. }\end{array}$ \\
\hline 11 & $7-3-16$ & $\begin{array}{l}\text { I think my biggest area 'needs improvement' is classroom management. Because, during my practicum I have } \\
\text { realized that each student in the class is exhibiting different disruptive behavior. I need more time and } \\
\text { experience to understand them. I am pretty new at this. That means that I have no experience to guide me in all } \\
\text { of the split-second questions that come up over the course of the day. }\end{array}$ \\
\hline 12 & $11-3-16$ & $\begin{array}{l}\text { Today an exam was held. It was surprising that some students finished the exam within a very short time. I have } \\
\text { realized that I did not include many parts in the exam. Great mistake really... I will not do it again. }\end{array}$ \\
\hline 9 & $21-3-16$ & $\begin{array}{l}\text { 'I can hardly say that the lesson was good. At the beginning of the lesson, I was quite anxious and my hands } \\
\text { were trembling while I was showing the story. Later, I realized that some students were not interested in what I } \\
\text { was talking about ... Then I noticed some disrupted behaviours, so I just wanted to end the presentation as soon } \\
\text { as possible... }\end{array}$ \\
\hline 1 & $18-3-16$ & $\begin{array}{l}\text { My greatest strength as a teacher, I feel, is my ability to relate to the students and to employ different methods } \\
\text { incorporating other disciplines. I have now learnt quite practical tips to help students learn through reflective } \\
\text { writing program. What I learned here will definitely make me incorporate different concepts of role play into } \\
\text { my teaching of sociology in many ways. }\end{array}$ \\
\hline
\end{tabular}

\section{2. (DR) Descriptive Writing}

\begin{tabular}{ccl}
\hline Journal No. & Entry Date & \multicolumn{1}{c}{ Journal Excerpt } \\
\hline 13 & $17-3-16$ & $\begin{array}{l}\text { Implementing the learning cycle worked and proved to be a useful tool, even though I was very sceptic at the } \\
\text { beginning. }\end{array}$ \\
\hline 5 & $9-3-16$ & $\begin{array}{l}\text { Ii is good to see that teacher today looks very confident and I understand she has made careful preparations. } \\
\text { This sort of activity can really work to involve all students in learning. Today they have really cooperated well } \\
\text { and it seems that teacher is happy with what she is doing. }\end{array}$ \\
\hline 2 & $15-3-16$ & At last I have been able discuss with the director and sort out time-table clashes. I love her. \\
\hline 6 & $14-3-16$ & $\begin{array}{l}\text { Through brainstorming most students could get a rough idea on the content of teaching to be dealt in today's } \\
\text { lesson. Video script that the teacher has chosen created curiosity and they could relate to the topic on how } \\
\text { workers generate income. }\end{array}$ \\
\hline 11 & $18-3-16$ & $\begin{array}{l}\text { I include so many creative activities in my class, however, time is not enough. Incorporating all of the activities } \\
\text { my students would like is tough. However, I have learnt how to prioritize the most important lessons to courage } \\
\text { my students in the course of time. I may say that doing everything I wish is not easy. }\end{array}$ \\
\hline 9-3-16 & $\begin{array}{l}\text { Teaching method applied today did not match with teaching objectives. The lesson planned and the way teacher } \\
\text { delivered was quite different. }\end{array}$ \\
\hline
\end{tabular}

\section{3. (CR) Critical Reflection}

\begin{tabular}{cll}
\hline Journal No. & Entry Date & \multicolumn{1}{c}{ Journal Excerpt } \\
\hline 7 & $12-3-16$ & $\begin{array}{l}\text { Although throughout my training to date, I have tried to reflect on various clinical situations and considered } \\
\text { learning objectives within the practice portfolio; I can hardly say that I had actually taken on the implications of } \\
\text { what it is to be a truly reflective practitioner. I have long way to go... }\end{array}$ \\
\hline 12 & $\begin{array}{l}\text { Every student is unique and to win the heart and belief of each student, I approach everyone individually. This } \\
\text { seems to be my strength. But, I try to treat everyone equally regarding ranking, as it would be very demotivating } \\
\text { for the better children to get the same marks as the others get. Meanwhile, I am quite open to use both attitudes, } \\
\text { equal and not equal, depends on the philosophy of your school. Teachers must be unified in this. }\end{array}$ \\
\hline 13 & $\begin{array}{l}\text { There is a huge difference among the teachers in using the teacher and learner talk time. It is not easy to figure } \\
\text { out how to balance it. }\end{array}$ \\
\hline 5 & $\begin{array}{l}\text { I now realize the importance of time management. During the pre, while and post sections of the lesson, I } \\
\text { overestimated time management principles. Furthermore, I did not know that teacher talk time in my teaching } \\
\text { would be much more than learner talk time. How should I arrange it? }\end{array}$ \\
\hline 11 & $\begin{array}{l}\text { I tend to be over friendly to students, what is not always good. Nevertheless, I am aware of this and try to keep } \\
\text { some distance. When examined my strengths, I can talk about good listening skills and an ability to grasp the } \\
\text { problems and emotions of the students in a short time. }\end{array}$ \\
\hline
\end{tabular}




\section{4. (DR) Descriptive Reflection}

\begin{tabular}{cll}
\hline Journal No. & Entry Date & Journal Excerpt \\
\hline 8 & $8-3-16$ & $\begin{array}{l}\text { It is hard to balance between students who are active and those are passive. The teacher was fair enough to } \\
\text { deliver the right to answer questions, however, some overused the time and teacher could not stop them. }\end{array}$ \\
\hline 31 & $5-3-16$ & $\begin{array}{l}\text { It is nice to see that some students were cooperative during discussions however, some other were quite passive. } \\
\text { It is good to see that teacher all the names and when she calls the students by their name, they attempt to } \\
\text { participate. }\end{array}$ \\
\hline $20-3-16$ & $\begin{array}{l}\text { It is the first time I have seen such noisy students. I do not like them at all. I feel sorry for the teacher. ... } \\
27\end{array} \quad \begin{array}{l}\text { The critical and creative thinking skills through brainstorming seem to have failed today. May be cognitive } \\
\text { levels of the students were not much developed to understand the questions of the teacher. }\end{array}$ \\
\hline 22 & $\begin{array}{l}\text { At last, teacher today employed a jigsaw to test the pre learnings of the student. And it worked. Students were } \\
\text { highly motivated and they did not want the lesson to finish. }\end{array}$ \\
\hline
\end{tabular}

\section{Appendix II: Percentages of Reflection Types}

\begin{tabular}{ccc}
\hline Reflection Type & $\begin{array}{c}\text { Frequency of Reflection } \\
\text { Type }\end{array}$ & Percentage \\
\hline DIAR & 70 & $35 \%$ \\
DW & 58 & $29 \%$ \\
CR & 52 & $26 \%$ \\
DR & 20 & $10 \%$ \\
\hline TOTAL & 200 & $100 \%$ \\
\hline
\end{tabular}

\section{Appendix III: Sample Questions}

Q1: Does journal writing help you in:
(a) determining your

\section{Note} attributes as a teacher?

(b) improving/developing yourself as a teacher?

(c) defining to what extent you have succeeded as a teacher?

(d) identifying your weaknesses as a teacher?

(e) determining a good, creative and effective teacher characteristics?

(f) developing your understanding/philosophy of learning and teaching processes and of the curricula?

Q2: Does writing journal help in improving yourself as a teacher?

Q3: Does writing journal help in the learning and teaching process?

Q4: Does writing journal help in:

(a) fulfilling your teaching objectives?

(b) identifying what is to be taught?

(c) evaluating the teaching aids you used?

(d) realizing what you have learnt and practiced?

(e) evaluating the activities that you have chosen?

(f) evaluating the teaching methods employed?

(g) identifying any problems in your teaching?

(h) evaluating your teacher-student relationship?

(i) evaluating the decision-making in the learning and teaching process?

(j) evaluating the problem-solving method you used? (k) determining the unsuccessful aspects of your teaching?

(1) determining the successful aspects in your teaching?

(m) determining changes that you should make?

(n) identifying new aspects in your teaching?

Q5: What is that leads you to write a reflective journal apart from a writing assignment?

Q6: Do you like this journal writing?

Q7: Give a brief summary of your opinions and experience on journal writing.

*The abstract of this paper was presented at 2nd International Conference on Lifelong Learning and Leadership for All (ICLEL-16), in Liepaja on July, 21-23, 2016.

\section{REFERENCES}

[1] Bean, T.W., and Zulich,J. (1989). Using dialogue journals to foster reflective practice with preservice, content-area teachers. Teacher Education Quarterly, 16(1), 33-40.

[2] Bolton, G. (2010). Reflective practice: writing and professional development. 3rd ed. London: Sage.

[3] Boud, D. (2001). Using journal writing to enhance reflective practice. In L.M. English \& M.A. Gillen (Eds.), Promoting journal writing in adult education (pp. 9-18). San Francisco, CA: Jossey-Bass.

[4] Brookfield, S. (1987). Developing critical thinkers: Challenging adults to explore alternative ways of thinking and acting. San Francisco, CA: Jossey-Bass.

[5] Farrell, T.S.C. (1999). Teachers talking about teaching: Creating conditions for reflection. TESL-EJ. http://www-writing.berkeley.edu/TESL-EJ/ej14/a1.html

[6] Cunliffe, A. (2004). On becoming a critically reflexive practitioner. Journal of Management Education, 28(4), 407-426. 
[7] Dyment, J.E. and O'Connell, T.S. (2003). Journal writing in experiential education: possibilities, problems, and recommendations. Charleston, WV: ERIC Clearinghouse on Rural Education and Small Schools. (ERIC Document Reproduction Service No. ED479358).

[8] Göker, Süleyman D. (2005). A School-based management and supervision model (SBMS) in EFL Schools. The Internet TESL Journal, January 2005.

[9] Göker, S. D. (2006a). Leading for learning: Reflective management in EFL. Theory into Practice. Spring 2006, Volume. 45, No. 2, pp.187-196.

[10] Göker, S. D. (2006b). Impact of peer coaching on self-efficacy and instructional skills in TEFL teacher education. System, And International Journal of Educational Technology and Applied Linguistics. 2006. 34/2 pp. 239-254.

[11] Göker, Süleyman D. (2012). Reflective Leadership in EFL. Theory and Practice in Language Studies. Vol.2, No. 8, August 2012.

[12] Hatton, N., and Smith, D. (1995). Reflection in teacher education: Towards definition and implementation. Unpublished manuscript. School of Teaching and Curriculum Studies, The University of Sydney, Australia.

[13] Lee-Davies, L. (2007). Developing work and study skills. London: Thomson

[14] Moon, J. (2006). Learning journals a handbook for reflective practice and professional development. 2nd ed. London: Routledge.
[15] Ramsey, V. J., \& Fitzgibbons, D. (2005). Being in the classroom. Journal of Management Education, 29(2), 333-356.

[16] Richards, J.C., and Lockhart, C. (1997). Reflective teaching in second language classrooms. Cambridge: Cambridge University Press.

[17] Schon, D. (1987). Educating the reflective practitioner. Paper presented to the 1987 meeting of the American Educational research Association, Washington, DC, 1-19. Posted by Tom Russell, Queen's University, January, 1998.

[18] Smith, L., and Pape, S.L. (1990). Reflectivity through journal writing: Student teachers Write about reading methods courses. Paper presented at the Annual Meeting of the Nation, Florida, 1990. (ERIC Document Reproduction Service No. ED 327498).

[19] Spaulding, E., \& Wilson, A. (2002). Demystifying reflection: a study of pedagogical strategies that encourage reflective journal writing. Teachers College Record, 104(7), 13031421.

[20] Varner, D., \& Peck, S. (2003). Learning from learning journals: The benefits and challenges of using learning journal assignments. Journal of Management Education, 27(1), 52-77.

[21] Gilmore, F. (1996). Qualitative research: Written journals within teacher training. Unpublished manuscript. Christchurch College of Education. Christchurch, New Zealand. 